Vaclav Linkov - Martina Trepacova - Veronika Kureckova - Chih-Wei Pai*

\title{
NOVICE CZECH DRIVERS' ABILITY AND WILLINGNESS TO OFFER THE FIRST AID AFTER TRAFFIC ACCIDENTS: THE POSITIVE EFFECT OF THE FIRST-AID TRAINING
}

The first aid is an important tool to save people's lives after traffic accidents. Drivers are the most-likely bystanders, who might help injured people at the traffic accident site. The current research aims to explore Czech learner drivers 'knowledge and attitudes towards the first aid and to evaluate whether the first aid education increases the likelihood that a driver will provide the first aid for injuries resulting from traffic accidents. A questionnaire survey was conducted in 2015 among a sample of 370 Czech learner drivers at driving schools. The two groups of student drivers were compared - those who had attended the first aid classes (FAC) and those who had not. The learner drivers who had attended an FAC are more likely to know how to treat burns and serious injuries, contain external bleeding, and unblock the respiratory track. Those who had not attended an FAC would more often hesitate to provide the first aid because they resisted taking a leadership role to organize the scene, or they did not have suitable equipment. This supports the idea that increasing the quality of the first aid training for Czech student drivers would improve the traffic safety in the Czech Republic.

Keywords: traffic accident injuries; the first aid education; learner drivers; driving schools

\section{Introduction}

Importance of the first aid training for improving safety has been acknowledged for a long time [1]. There is a great effort to provide the adequate first aid to people in need [2]. Since the first aid classes are included in the regular education [3], people are better trained to be able to provide the first aid, which increases its quality. Therefore, training people in the first aid is a way to improve the pre-hospital care for injured [4].

Not all the people know how to administer the first aid. For example, in Jordan, $72 \%$ of university students know how to treat a spinal fracture, but only $45 \%$ know how to check respiration and $37 \%$ to treat a burn [5]. Even people who might need it in their profession do not know how to provide the first aid: less than $20 \%$ of Slovenian kindergarten teachers know how to provide cardiopulmonary resuscitation or know what to do in the case of intoxication [6]. In Norway, where the first aid tends to be taught from the primary-school level [7], 90\% of the population surveyed by Bakke et al. [8] had received the first aid training and $72 \%$ of the population felt that they would be able to provide the first aid in case of an emergency. Of those who had had an opportunity to use the knowledge learned in an FAC, 78\% felt that the training had prepared them well. People who had attended an FAC were more knowledgeable about the necessity of providing the first aid after a traffic accident

Witnesses of accidents where the first aid is necessary might feel helpless and unable to provide the first aid [9]. They might feel too physically weak or that they lack enough knowledge to provide the first aid. They might also hesitate to provide the first aid because of the unpleasant circumstances, like patient vomiting, obesity or blood. The fear of an infectious disease might also lead to hesitation [10]. According to Bakke et al. [8], some people have reservations regarding providing the first aid - $12 \%$ are "unwilling to perform certain first aid measures" (p. 4) and one third of those ( $4 \%$ of the total sample) have these reservations because of a fear of infection. Reservations regarding the first aid are not related to presence or absence of the first aid training [8].

Driver training and the ability to provide the first aid vary around the world. In Nigeria, $76 \%$ of professional drivers know how to make sure that a patient is breathing properly, $90 \%$ know how to stop bleeding and $76 \%$ know how to treat fractures [11]. Only $32 \%$ of Ethiopian taxi drivers can identify the correct first step for providing the first aid, $28 \%$ know how to unblock an obstructed airway, $12 \%$ know how to apply direct pressure to serious bleeding, and $20 \%$ know how to transport an unconscious patient [12]. Larsson et al. [13] report that $7 \%$ of Swedish drivers trained in the first aid actually used their knowledge after a traffic accident. Over $80 \%$ of Polish drivers would offer the first aid in the case of an accident, $60 \%$ of Polish drivers would hesitate to offer the first aid because of their lack of competence, $20 \%$ would hesitate because they are afraid of their own health and $10 \%$ would hesitate because of possible legal consequences. About $40 \%$ Polish drivers know how to unblock the respiratory track, $24 \%$ know how to make the chest compressions and $60 \%$ know how to treat a person with a spinal injury [14]. The ability to provide the first aid might also be influenced by the fact that traffic accidents mostly happen when drivers are tired [15], so the witnesses may also be tired.

Research generally shows that when drivers attend an FAC, it increases their ability to provide the first aid. Adelborg et al. [16] compared the first aid knowledge of Danish learner drivers before and after they took an FAC. Knowledge to prioritize the

\footnotetext{
* ${ }^{1}$ Vaclav Linkov, ${ }^{1}$ Martina Trepacova, ${ }^{1}$ Veronika Kureckova, ${ }^{2}$ Chih-Wei Pai ${ }^{1} \mathrm{CDV}$ - Transport Research Centre, Brno, Czech Republic

${ }^{2}$ Graduate Institute of Injury Prevention and Control, College of Public Health, Taipei Medical University, Taipei, TAIWAN Email: vaclav.linkov@hotmail.com
} 
treatment among several casualties increased to $95 \%$ from $62 \%$; how to control arterial bleeding to $75 \%$ from $30 \%$; how to relieve a foreign body from airway construction to $97 \%$ from $68 \%$; how to offer the first aid for a neck injury to $89 \%$ from $77 \%$; and for shock to $71 \%$ from $50 \%$; while the knowledge of how to offer the first aid for a concussion did not increase $(84 \%$ before, $80 \%$ after). In a Polish sample, $8 \%$ of drivers would not offer help because they were afraid that they might harm the patient [17] When the knowledge of drivers who had attended an FAC was compared with those who had not, the knowledge about checking for consciousness was $60 \%$ for the former and $47 \%$ for the latter; for checking the breathing it was $42 \%$ and $27 \%$, respectively and for how to synchronize chest compression with rescue breaths $62 \%$ and $47 \%$, respectively [17]. Vakili et al. [18] collected a sample of 500 professional Iranian drivers who had encountered a traffic accident and gave them the first aid training. Before the training they asked whether they had provided the first aid in the accident(s) they had encountered. Six months after the training they asked those drivers who had encountered a new accident the same questions and compared whether the percentage of those who provided the first aid had improved. The percentage of those who administered the first aid increased to $96 \%$ from $65 \%$ for airway management; to $98 \%$ from $79 \%$ for control of bleeding; to $97 \%$ from $71 \%$ for fracture management; and to $92 \%$ from $55 \%$ for putting the injured person in a recovery position.

In this study the focus was on the first aid skills of Czech learner drivers. Children in Czech primary schools have about 4 hours of the first aid classes every year from the $5^{\text {th }}$ to the $9^{\text {th }}$ grade. Czech learner drivers additionally have four hours of the first aid classes during their driving course. Nevertheless, those classes consist only of watching videos and students do not practice the skills. Only about $60 \%$ of Czech drivers would give the first aid after a traffic accident [19]. This situation might be improved if additional first aid training is incorporated into Czech driving courses [20]. This research aims to assess Czech drivers' ability to provide specific types of the first aid and the obstacles they might feel when deciding to administer it. While Kureckova et al. [20] compared different types of the first aid training for learner drivers, the aim here is to show that any type of training is efficient in comparison to absence of training: The differences between drivers who have attended the first aid classes (FAC) and those who have not were compared through a questionnaire. In this way the intention was to bring additional evidence that the first aid training increases the traffic safety in the Czech Republic.

\section{Study}

\section{Sample}

Hundred and twenty driving schools in the South Moravian, Vysocina, Olomouc, and Prague regions of the Czech Republic were contacted. They were asked whether they would distribute a questionnaire to their students. Six of the schools agreed to do so, two in Brno, two in Trebic, one in Olomouc, and one in Prague. We distributed the questionnaire among their students in the end of 2013 and the first half of 2014. The sample consisted of 400 participants, however, 30 questionnaires were excluded for too many missing answers resulting in having data from 370 subjects - 312 men, 53 women and 5 did not provide their gender. The mean age of the participants was $21.2(\mathrm{SD}=7.2)$. More than a half of the participants $(n=189,52 \%)$ took the first aid course, the rest $(n=181)$ had no experience with the first aid course.

\section{Measure}

The questionnaire was created by Adelborg et al. [16], which was translated to the Czech language by professional interpreter. The questionnaire contains questions about gender and age; whether the participant had experience with providing the first aid, had ever attended some first aid course and had witnessed a traffic accident. It contained the 5-point Likert scale (rating scale with five rankings: certainly yes, rather yes, I don't know, rather no, certainly no) items about whether the subject was able and willing to provide the first aid after a traffic accident, what kind of the first aid the participant thought they would be able to offer and how satisfied they were with the first aid education in their driving school. There were several 4-point Likert scales (certainly yes, rather yes, rather no, certainly no) about why the participant might hesitate to offer the first aid (the reasons for refusing the first aid are in Table 3).

\section{Results}

This study aims to determine whether groups of those who attended the first aid course and those who did not differ in their declared knowledge of the first aid and the willingness to provide it. The t-tests for independent samples were used for analysis of obtained data. All reported probability values are two-tailed. For all analyses, an alpha of .05 or .01 was used. The assumptions of normality and the homogeneity of variance were examined and met. The percentages in the text below mean how many people answered "certainly yes" or "rather yes" on the Likert scales.

The majority of participants $(n=287,78 \%)$ did not have experience with providing the first aid. The length of the traffic aid course was an average of 4.8 hours $(\mathrm{SD}=8.4$ ). A quarter of the participants $(n=102,28 \%)$ had witnessed a traffic accident.

The majority of participants $(n=226,62 \%)$ felt that they would be able to provide the first aid after a traffic accident. Those who had attended the first aid course felt more confident about their ability than those who had not $(\mathrm{t}=2.8, \mathrm{p}<.01)$.

The majority $(n=282,78 \%)$ knew how to stop large-scale external bleeding; those who had attended an FAC knew how to contain it more often than those who had not $(t=2.2, p<.05)$. Participants $(n=211,58 \%)$ also knew how to treat burns; those who had attended an FAC knew more often than those who had not $(\mathrm{t}=2.0, \mathrm{p}<.05)$. Only one third of the participants $(\mathrm{n}=123$, $34 \%)$ knew how to treat a spinal or neck injury; those who had attended an FAC knew it more often $(\mathrm{t}=2.7, \mathrm{p}<.01)$. Over three quarters $(\mathrm{n}=286,78 \%)$ knew how to provide chest compressions. Three quarters $(\mathrm{n}=273,75 \%)$ knew how to unblock the respiratory track; those who had attended an FAC knew it more often $(t=2.0, p<.05)$. More than a half of participants $(n=190$, $52 \%)$ knew how to treat a serious injury; those who had attended an FAC knew it more often $(\mathrm{t}=3.0, \mathrm{p}<.01)$. Nearly all of the participants $(n=349,96 \%)$ knew how to call for help. See Tables 1 and 2 for details. 
Table 1 Descriptions of participants who had and had not attended the first aid course (FAC)

\begin{tabular}{|c|c|c|c|c|c|c|}
\hline \multirow[b]{2}{*}{ Item } & \multicolumn{2}{|c|}{$\begin{array}{c}\text { Certainly yes or rather } \\
\text { yes }\end{array}$} & \multicolumn{2}{|c|}{$\begin{array}{l}\text { Certainly/ rather yes and } \\
\text { attended the FAC }\end{array}$} & \multicolumn{2}{|c|}{$\begin{array}{l}\text { Certainly/ rather yes and } \\
\text { did not attend the FAC }\end{array}$} \\
\hline & $\mathrm{n}$ & $\%$ & $\mathrm{n}$ & $\%$ & $\mathrm{n}$ & $\%$ \\
\hline Feels able to provide the first aid after a traffic accident & 226 & 61.8 & 128 & 68.4 & 93 & 55.4 \\
\hline \multicolumn{7}{|l|}{ Knows how to... } \\
\hline Stop large external bleeding & 282 & 76.2 & 153 & 81.8 & 121 & 72.0 \\
\hline Treat a burn & 211 & 57 & 119 & 63.6 & 86 & 51.2 \\
\hline Treat a spinal or neck injury & 123 & 33.2 & 70 & 37.6 & 47 & 28.0 \\
\hline Provide chest compressions & 286 & 77.3 & 146 & 78.1 & 135 & 80.4 \\
\hline Clear the lungs/unblock respiratory track & 273 & 73.8 & 144 & 77.0 & 124 & 73.8 \\
\hline Prioritize serious injuries & 190 & 51.4 & 107 & 57.2 & 75 & 44.6 \\
\hline \multirow[t]{2}{*}{ Call for help } & 349 & 94.3 & 178 & 95.2 & 161 & 95.8 \\
\hline & \multicolumn{2}{|c|}{$\mathrm{N}=370$} & \multicolumn{2}{|c|}{$\mathrm{N}=187$} & \multicolumn{2}{|c|}{$\mathrm{N}=168$} \\
\hline
\end{tabular}

Table 2 Differences in the first aid knowledge between participants who had and had not attended the first aid course (FAC)

\begin{tabular}{|c|c|c|c|c|c|}
\hline Item & M1 & M2 & $\mathrm{t}$ & $\mathrm{p}$ & $\mathrm{d}$ \\
\hline Feels able to provide the first aid after a traffic accident & 2.18 & 2.39 & 2.8 & 0.006 & .29 \\
\hline \multicolumn{6}{|l|}{ Knows how to... } \\
\hline Stop large external bleeding & 2.02 & 2.21 & 2.2 & 0.032 & .23 \\
\hline Treat a burn & 2.30 & 2.49 & 2.0 & 0.044 & .22 \\
\hline Treat a spinal or neck injury & 2.85 & 3.16 & 2.7 & 0.007 & .30 \\
\hline Provide chest compressions & 1.90 & 1.96 & 0.5 & 0.590 & \\
\hline Clear the lungs/unblock respiratory track & 1.89 & 2.08 & 2.0 & 0.042 & .22 \\
\hline Prioritize serious injuries & 2.40 & 2.70 & 3.0 & 0.003 & .32 \\
\hline Call for help & 1.20 & 1.17 & -0.5 & 0.630 & \\
\hline
\end{tabular}

Note: M1 - mean for those who had attended FAC, M2 - mean for those who had not attended FAC, t - Student's t - test value, $\mathrm{p}$ - statistical significance, d - Cohen's d

Table 3 Descriptions of participants who had and had not attended the first aid course (FAC) for a question: which of the following situations would stop them from providing the first aid

\begin{tabular}{|c|c|c|c|c|c|c|}
\hline \multirow[b]{2}{*}{ Item } & \multicolumn{2}{|c|}{$\begin{array}{l}\text { Certainly yes } \\
\text { or rather yes }\end{array}$} & \multicolumn{2}{|c|}{$\begin{array}{l}\text { Certainly/ rather yes } \\
\text { and attended the FAC }\end{array}$} & \multicolumn{2}{|c|}{$\begin{array}{l}\text { Certainly/ rather yes and } \\
\text { did not attend the FAC }\end{array}$} \\
\hline & $\mathrm{n}$ & $\%$ & $\mathrm{n}$ & $\%$ & $\mathrm{n}$ & $\%$ \\
\hline \multicolumn{7}{|l|}{ The following situation would stop me from providing the first aid: } \\
\hline Someone else will help or helps & 96 & 26 & 36 & 19.3 & 56 & 33.1 \\
\hline Someone else would see me, it is embarrassing & 29 & 7.8 & 14 & 7.5 & 14 & 8.3 \\
\hline I would not dare to organize others to provide help & 123 & 33.2 & 57 & 30.5 & 63 & 37.3 \\
\hline When no one else is helping there is no need to provide help & 57 & 15.4 & 19 & 10.2 & 36 & 21.3 \\
\hline I do not have suitable equipment & 79 & 21.4 & 34 & 18.2 & 43 & 25.4 \\
\hline I have suitable equipment but I do not know how to use it & 71 & 19.1 & 29 & 15.5 & 39 & 23.1 \\
\hline I have the first aid kit but I do not know how to use it & 35 & 3.7 & 11 & 5.9 & 23 & 13.6 \\
\hline I cannot ensure my own safety & 197 & 53.2 & 109 & 58.3 & 82 & 48.5 \\
\hline \multirow[t]{2}{*}{ Injury looks repulsive } & 131 & 35.4 & 61 & 32.6 & 67 & 40.1 \\
\hline & \multicolumn{2}{|c|}{$\mathrm{N}=370$} & \multicolumn{2}{|c|}{$\mathrm{N}=187$} & \multicolumn{2}{|c|}{$\mathrm{N}=169$} \\
\hline
\end{tabular}

Regarding the reasons someone would not offer the first aid after a traffic accident, $8 \%(29 / 357)$ said they would feel ashamed with someone observing them. One third (123/364, $34 \%$ ) would not because they would not dare organizing others to help; however, this would be a lesser obstacle for those who had attended an FAC than for those who had not $(\mathrm{t}=-2.5$, $\mathrm{p}<$
.05). One quarter of the participants (79/362, 22\%) would not offer the first aid because they feared that they might not have suitable equipment; this would be less of an obstacle for those who had attended an FAC $(\mathrm{t}=-2.5, \mathrm{p}<.05)$. For $20 \%$ of the participants (71/361), the lack of knowledge about how to use the first aid equipment would be a reason not to offer help; again, 
Table 4 Differences between participants who had and had not attended the first aid course (FAC) for question which of the following situations would stop them from providing the first aid

\begin{tabular}{|c|c|c|c|c|c|}
\hline Item & M1 & M2 & $\mathrm{t}$ & $\mathrm{p}$ & $\mathrm{d}$ \\
\hline \multicolumn{6}{|l|}{ The following situation would stop me from providing the first aid: } \\
\hline Someone else will help or helps & 3.18 & 2.83 & -3.2 & .002 & -.36 \\
\hline Someone else would see me, it is embarrassing & 3.56 & 3.51 & -.64 & .520 & \\
\hline I would not dare to organize others to provide help & 2.91 & 2.68 & -2.5 & .014 & -.26 \\
\hline When no one else is helping there is no need to provide help & 3.54 & 3.2 & -3.7 & .000 & -.39 \\
\hline I do not have suitable equipment & 3.23 & 3.02 & -2.5 & .013 & -.26 \\
\hline I have suitable equipment but I do not know how to use it & 3.24 & 3.01 & -2.6 & .009 & -.27 \\
\hline I have the first aid kit but I do not know how to use it & 3.10 & 3.20 & -1.1 & .230 & \\
\hline I cannot ensure my own safety & 2.29 & 2.48 & 1.8 & .07 & 0.2 \\
\hline Injury looks repulsive & 2.83 & 2.74 & -.88 & 0.38 & \\
\hline
\end{tabular}

Note: M1 - mean for those who had attended FAC, M2 - mean for those who had not attended FAC, $\mathrm{t}$ - Student's t-test value, $\mathrm{p}$ - statistical significance, d - Cohen's d

this would be more common for those who had not attended an FAC $(t=-2.6, p<.01)$ and other participants $(35 / 179,20 \%)$ did not know the contents of the first aid kit in their car. Half of the participants (197/360, 55\%) would not offer help when they could not guarantee their own safety. One third $(131,37 \%)$ would not offer help when an injury was grotesque or disgusting. See Tables 3 and 4 for details.

\section{Discussion and Conclusion}

Over one quarter of surveyed Czech student drivers had experience with a traffic accident and one fifth had provided some kind of the first aid. This is quite a large proportion of drivers and, given that they were not well informed about treating several types of injuries, this shows that improving the first aid training of Czech drivers is an important step to increasing the traffic safety.

The presented results support the argument that an FAC is associated with the ability to provide the first aid. Participants who had attended FACs felt more able to provide the first aid and more often knew how to treat specific health issues. The only exception was for the chest compressions: FAC students did not know more than those without an FAC. Additionally, the FAC also reduces some reservations that block people from helping. People with FAC experience would hesitate less to offer help because of a fear about not having the suitable equipment and being unable to organize others.

The sample and method that were used has several limitations. First, our sample was not randomly selected. This enhances probability of a sample bias. Second, the large number of statistical comparisons were performed, so the probability of type 1 error increased. Third, the sample represents only central and south eastern part of the Czech Republic and it is questionable whether the results could be generalized to the whole country.

Obtained results support the hypothesis that the first aid training is important for boosting self-confidence for providing the first aid. Health educators should provide the best possible first aid training to learner drivers. With increased training, the number of people who actually would help will probably increase and many human lives could be saved. The recommendation is to increase the number of the first aid lectures for the learner drivers with the aim of improving the traffic safety. The first aid is more important after the traffic accidents for the elderly patients, because they die before reaching the hospital more often than the younger people [21]. It would be beneficial if the first aid training was organized for older drivers who might more often have the opportunity to save other elderly patients' lives. The first aid training makes people behave safer in their normal life [22]. Training learner drivers in the first aid might help to increase the general safety of society.

\section{Acknowledgements}

This research was produced with the financial support of the Ministry of Education, Youth and Sports within National Sustainability Programme I, a project of the Transport R\&D Centre (LO1610), on a research infrastructure acquired from the Operation Programme Research and Development for Innovations (CZ.1.05/2.1.00/03.0064).

\section{References}

[1] GLENDON, A. I., MCKENNA, S. P. Using accident injury data to assess the impact of community first aid training. Public Health [online]. 1985, 99(2), p. 98-109. ISSN 0033-3506/eISSN 1476-5616. Available from: https://doi.org/10.1016/S00333506(85)80006-8

[2] VAN DE VELDE, S., et al. European first aid guidelines. Resuscitation [online]. 2007, 72(2), p. 240-251. ISSN 0300-9572/eISSN 1873-1570. Available from: https://doi.org/10.1016/j.resuscitation.2006.10.023 
[3] WILKS, J., PENDERGAST, D. Skills for life: First aid and cardiopulmonary resuscitation in schools. Health Education Journal [online]. 2017, 76(8), p. 1009-1023. ISSN 0017-8969/eISSN 1748-8176. Available from: https://doi.org/10.1177/0017896917728096

[4] IBRAHIM, N., A., et al. Road traffic injury in Lagos, Nigeria: Assessing prehospital care. Prehospital and Disaster Medicine [online]. 2017, 32(4), p. 1-7. ISSN 1049-023X/eISSN 1945-1938. Available from: https://doi.org/10.1017/S1049023X17006410

[5] KHATATBEH, M. First aid knowledge among university students in Jordan. International Journal of Preventive Medicine [online]. 2016, 7(1), p. 24. ISSN 2008-7802/eISSN 2008-8213. Available from: https://doi.org/10.4103/2008-7802.174772

[6] SLABE, D., FINK, R. Kindergarten teachers' and their assistants' knowledge of first aid in Slovenian kindergartens. Health Education Journal [online]. 2012, 72(4), p. 398-407. ISSN 0017-8969/eISSN 1748-8176. Available from: https://doi. org/10.1177/0017896912446555

[7] BAKKE, H., K., BAKKE, H., K., SCHWEBS, R. First-aid training in school: Amount, content and hindrances. Acta Anaesthesiologica Scandinavica [online]. 2017, 61, p. 1361-1370. ISSN 0001-5172/eISSN 1399-6576. Available from: https://doi.org/10.1111/aas.12958

[8] BAKKE, H., K., et al. A nationwide survey of first aid training and encounters in Norway. BMC Emergency Medicine [online]. 2017, 17(6), p. 1-7. eISSN 1471-227X. Available from: https://doi.org/10.1186/s12873-017-0116-7

[9] AXELSSON, Å., HERLITZ, J., FRIDLUND, B. How bystanders perceive their cardiopulmonary resuscitation intervention; a qualitative study. Resuscitation [online]. 2000, 47(1), p. 71-81. ISSN 0300-9572/eISSN 1873-1570. Available from: https://doi. org/10.1016/S0300-9572(00)00209-4

[10] SKORA, J., RIEGEL, B. Thoughts, feelings, and motivations of bystanders who attempt to resuscitate a stranger: A pilot study. American Journal of Critical Care. 2001, 10(6), p. 408-416. ISSN 1062-3264/eISSN 1937-710X.

[11] OLUGBENGA-BELLO, A., I., et al. First aid knowledge and application among commercial inter-city drivers in Nigeria. African Journal of Emergency Medicine [online]. 2012, 2(3), p. 108-113. ISSN 2211-419X/eISSN 2211-4203. Available from: https://doi. org/10.1016/j.afjem.2012.06.003

[12] TESHALE, A., A., ALEMU, Z., A. Knowledge, attitude and practice of first aid and factors associated with practice among taxi drivers in Addis Ababa, Ethiopia. Ethiopian Journal of Health Development [online]. 2017, 31(3), p. 200-207. ISSN 1021-6790/ eISSN 2309-7388. Available from: https://www.ejhd.org/index.php/ejhd/article/view/1357/1015

[13] LARSSON, E., M., MARTENSSON, N., L., ALEXANDERSON, K., A., E. First-aid training and bystander actions at traffic crashes - A population study. Prehospital and Disaster Medicine [online]. 2002, 17(3), p. 134-141. ISSN 1049-023X/eISSN 19451938. Available from: https://doi.org/10.1017/S1049023X00000352

[14] FRYDRYSIAK, K., GRZESKOWIAK, M. Czy kierowcy potrafia udzielic pierwszej pomocy poszkodowanemu w wypadku drogowym? / Can drivers give first aid to causalities in road accident? (in Polish). Anestezjologia i Ratownictwo [online]. 2013, 7, p. 305-311. ISSN 1898-0732. Available from: http://www.akademiamedycyny.pl/wp-content/uploads/2016/05/201303_AiR_005.pdf

[15] Tvarozkova, L., et al. Unava za volantem, rizikove casy behem dne a dopravni nehodovost / Drowsy driving, vulnerable times of the day and traffic accidents (in Czech). Psychologie a jeji kontexty [online]. 2017, 8(2), p. 85-100. ISSN 1803-9278/ ISSN 1805-9023. Available from: http://psychkont.osu.cz/fulltext/2017/2017_2_7_Tvarozkova.pdf

[16] ADELBORG, K., et al. Benefits and shortcomings of mandatory first aid and basic life support courses for learner drivers. Resuscitation [online]. 2011, 82(5), p. 614-617. ISSN 0300-9572/eISSN 1873-1570. https://doi.org/10.1016/j.resuscitation.2010.12.018

[17] KARYS, J., et al. Knowledge of first aid in road traffic accidents among drivers from the Staszow County. Archives of Physiotherapy and Global Researches [online]. 2015, 19(1), p. 29-33. ISSN 2353-4389/eISSN 2353-7183. Available from: https://doi.org/10.15442/ apgr.19.2.4

[18] VAKILI, M., A., et al. The efficacy of a first aid training course for drivers: An experience from northern Iran. Chinese Journal of Traumatology [online]. 2014, 17, p. 289-292. ISSN 1008-1275. Available from: https://doi.org/10.3760/cma.j.i ssn.1008-1275.2014.05.008

[19] ZAMECNIK, P., et al. Vyuka prvni pomoci v autoskolach - zbytecnost nebo relevantni opatreni s velkym potencialem? / First aid training in driving schools - uselessness or relevant measure with considerable potential? (in Czech). Psychologie a jeji kontexty [online]. 2014, 5(Suppl.), p. 107-115. ISSN 1803-9278/ ISSN 1805-9023. Available from: http://psychkont.osu.cz/fulltext/2014/ Zamecnik_etal_2014_S.pdf

[20] KURECKOVA, V., et al. First aid as an important traffic safety factor - Evaluation of the experience-based training. European Transport Research Review [online]. 2017, 9(5), p. 1-8. ISSN 1867-0717/eISSN 1866-8887. Available from: https://doi.org/10.1007/ s12544-016-0218-4

[21] KATAYAMA, Y., et al. Factors associated with prehospital death among traffic accident patients in Osaka City, Japan: A population-based study. Traffic Injury Prevention [online]. 2017, 19(1), p. 49-53. ISSN 1538-9588/eISSN 1538-957X. Available from: https://doi.org/10.1080/15389588.2017.1347645

[22] LINGARD, H. The effect of first aid training on Australian construction workers' occupational health and safety motivation and risk control behavior. Journal of Safety Research [online]. 2002, 33(2), p. 209-230. ISSN 0022-4375/eISSN 1879-1247. Available from: https://doi.org/10.1016/S0022-4375(02)00013-0 